\title{
SOME ISSUES ON BIOLOGY EDUCATION: AN INTERVIEW WITH ANDREJ ŠORGO
}

\author{
Vincentas Lamanauskas \\ Šiauliai University, Lithuania
}

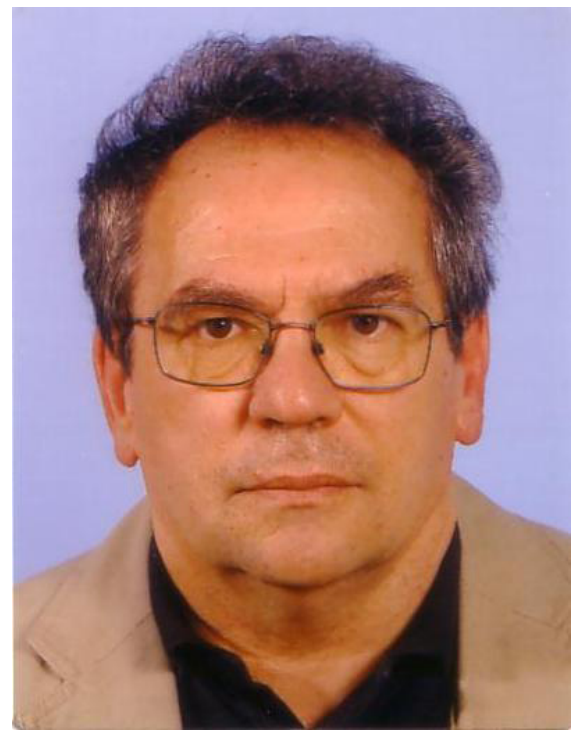

Dr. Andrej Šorgo is Associate Professor of Biology Didactics at the Faculty of Natural Sciences and Mathematics, and a part time researcher at the Faculty of Electrical Engineering and Computer Science, University of Maribor. He got his Masters and $\mathrm{PhD}$ degrees in Biology from the University of Ljubljana. He has published textbooks and research articles and presented his work at a number of conferences. He has additionally over 20 years of experience as a secondary and higher vocational school teacher. He has won the award "Most innovative secondary school teacher".

More information is available online at: http://biologija.fnm.uni-mb.si/index. php?option=com_content $\&$ view $=$ arti cle\&id=55\&Itemid $=7 \&$ lang $=$ en

It would be interesting to know a bird's-eye-view of the biology education system in your country in general, that is from primary to tertiary level. Can you describe it shortly?

Andrej: In Slovenia, 9-years elementary school is compulsory and covers primary (ISCED 1) and lower secondary school (ISCED 2) levels (Table 1). The majority of the schools are public and only a handful of schools are private following the same programme as public schools or programmes based on Waldorf and Montessori pedagogics. All public schools follow the same programme, curricula and subject syllabi approved by governmental bodies. The majority of the subjects are compulsory, and only in the last three years' elective subjects are offered (Table 2). 
Table 1. Structure of the Slovene elementary and secondary school system.

Tertiary education

\begin{tabular}{llllll}
\hline \multicolumn{5}{c}{ Compulsory exams at the end of secondary education } \\
\hline Grades & Age & $\begin{array}{l}\text { General } \\
\text { Matura }\end{array}$ & $\begin{array}{l}\text { Vocational } \\
\text { Matura }\end{array}$ & Vocational Matura & Matura course* \\
\hline $13-14$ & $18-19$ & & & $\begin{array}{l}\text { Vocational-technical } \\
\text { education** }\end{array}$ & \\
\hline $10-13$ & $15-18$ & $\begin{array}{l}\text { General } \\
\text { (4-years) }\end{array}$ & $\begin{array}{l}\text { Technical } \\
\text { (4-5 years) }\end{array}$ & $\begin{array}{l}\text { Vocational (3-4 } \\
\text { years) }\end{array}$ & $\begin{array}{l}\text { Short } \\
\text { vocational } \\
\text { (2-3 years) }\end{array}$ \\
\hline
\end{tabular}

Upper secondary education

\begin{tabular}{lll}
\hline $7-9$ & $12-14$ & Third cycle (lower secondary education) -3 years \\
\hline $4-6$ & $9-11$ & Second cycle (primary education) -3 years \\
\hline $1-3$ & $6-8$ & First cycle (primary education) -3 years \\
\hline
\end{tabular}

\section{Elementary education}

Note. ${ }^{*}$ general upper secondary second chance education; $* * 2$ years of technical upper secondary education built on previously completed programme

Table 2. Compulsory and elective STEM subjects with biological content and weekly hours dedicated to the subjects in compulsory 9-year public schools.

\begin{tabular}{|c|c|c|c|c|c|c|c|c|c|c|}
\hline Subject / Grade & 1 & 2 & 3 & 4 & 5 & 6 & 7 & 8 & 9 & Sum \\
\hline Environmental Studies & 3 & 3 & 3 & & & & & & & 315 \\
\hline Science and Technology & & & & 3 & 3 & & & & & 210 \\
\hline Science & & & & & & 2 & 3 & & & 175 \\
\hline Biology & & & & & & & & 1,5 & 2 & 116.5 \\
\hline Elective subjects & & & & & & & $2-3$ & $2-3$ & $2-3$ & $240 / 306$ \\
\hline Science days (days/year) & 3 & 3 & 3 & 3 & 3 & 3 & 3 & 3 & 3 & \\
\hline
\end{tabular}

Upper secondary education can be broadly divided into 4-years Gimnazija programmes and programmes geared toward technical and vocational education.

Gimnazija programme is further structured into general, classic, sport, economic, arts and technical streams with adjustments of some subjects. However, regardless of the stream, main intention of the general secondary education is to prepare students for General Matura Exams, which serve as final exams to finish Gimnazija programme and as entrance exam to the university studies. Biology is offered 
Table 3. Compulsory STEM subjects in general secondary education (General Gimnazija programme).

\begin{tabular}{llllll} 
Subject / Grade & 1 & 2 & 3 & 4 & Sum \\
\hline Mathematics & 4 & 4 & 4 & 4 & 560 \\
Biology & 2 & 2 & 2 & $4^{1}$ & $210(350)$ \\
Chemistry & 2 & 2 & 2 & $4^{1}$ & $210(350)$ \\
Physics & 2 & 2 & 2 & $4^{1}$ & $210(350)$
\end{tabular}

1) Elective for students who choose one or two elective science subjects as part of the general Matura examination.

In technical (4-years) and vocational schools (2 -5 years), diversity is much greater what depends on intended outcomes of a programme. Biology can be taught as a separate subject or as integrated in subjects like Science, Science and Environment, etc. It is common that only part of the field of a general subject is covered (for example Microbiology, Human Anatomy). Programmes ended with obligatory final exams -Vocational Matura - what allows students to continue studies in higher non-university professional oriented studies, and by addition of one of the subjects at General Matura levels, some, mostly technical, University programmes.

To finish secondary education every student has to pass governmental exam named Matura, in a general or vocational form. General Matura is in addition entrance exam for most of the University degree studies. General Matura is composed from five subjects. Three subjects (Mother tongue, Mathematics, and one foreign language) are compulsory and two subjects are elective. Biology is offered as an elective subject at most schools with general Matura.

It is obvious that teaching is a very important profession. Teachers need to be welleducated. How biology teachers are educated in your country?

Andrej: Recently all elementary and secondary school teachers in Slovenia, regardless of educational stream(s) are obliged to achieve at least 60 ECTS from educational subjects (from total of 300 ECTS at the university master levels). Additionally, during the first three years, when employed as teachers, they should pass a state professional exam.

Courses for prospective Biology teachers are offered as a two-stream study at the Faculty of education of University of Ljubljana and Faculty of Natural Sciences and Mathematics of University of Maribor. The difference is, that in Ljubljana study is offered as 4 years at the baccalaureate level and additional year at the Master level. In Maribor they offered unified 5-years study. The other difference is that in Ljubljana only combinations of Biology - Chemistry and Biology - Home economics are available, while in Maribor students can combine Biology with Chemistry, Physics, Mathematics, Technics and Computer sciences. With two stream combination teachers are allowed to teach at elementary schools, and most secondary schools. Exception are gimnazija programmes (general upper secondary school) preparing for the General Matura state exams. Gimnazija teachers are by rule one stream Biology teachers, an educational programme offered at the Department of Biology at the Biotechnical Faculty of University of Ljubljana. Additionally, someone who finished Master level study of non-educational Biology at the Universities of Maribor and Ljubljana, can get licence by addition of 60 ECTS of missing educational subjects, offered as in-service university courses. 
Research doctorate in educational sciences is offered at a number of institutions allowing to combine biological topics and education, however due to limited number of potential candidates, a specialized programme in Biology education is not offered.

It is a well-known fact that students' motivation to learn is a key element in education. If children are motivated to learn and if we enable each one to learn effectively, we will have an education system with a great performance level. What about students' motivation to learn biology in your country?

Andrej: Students in general like biological topics, however they do not necessary share this opinion about all topics taught in schools and they would prefer if they will be taught in a more interesting and engaging way. Because Biology is compulsory in the last two years of elementary school, we do not have external measure of interest at these levels. The same is true for general secondary education, where Biology is elective at first as preparation course for Matura exam in the fourth year. We are nowadays witnesses that interest toward election of one of the science subjects, biology included, at Matura exams raise again, however numbers are still far below numbers of them who elected social science subjects. Biology study at the university levels, and most streams of the life science studies (e.g. Medicine, Veterine) do not have problems with filling study places, what is not a case of many other science disciplines and engineering studies. The real problem for future position of Biology and Science in schools is lack of interest to elect streams leading toward educational careers.

\section{What are the qualities of a good biology teacher (or science teacher, in general) from your point of view?}

Andrej: From my personal experiences as a teacher and teacher educator, I cannot point to only one single trait, but to a combination of them. Not necessary in this order, a Biology teacher should be curious and able to share enjoyment of inquiry of new knowledge and experiences with students. Teachers should be aware that knowledge is fluid and dynamic and that some issues what were taught as a law in their student times are not valid anymore. Research experiences can help because skills gained in process of scientific publishing can be transferred into work with students. Everyone who at some point start to believe that teaching career is Valley of Tears leading toward Green pastures of retirement should leave school immediately.

Biology education currently faces several critical issues. What, in your opinion, are the key challenges in biology education?

Andrej: Biology is in my opinion the most complex of all science disciplines, because living systems are in reality systems combined of many hierarchical systems and connected to the social sciences as well. The most important challenges should be: 1) Development of appropriate strategies that will help students to transfer and connect knowledge between hierarchical levels from subcellular levels to ecosystem. 2) Avoiding trap of descriptivism and reductionism, because life is a process not a thing. 3) Replacement of first-hand experiences with organisms in school laboratories and nature with virtual worlds. 4) Because of fast development of discipline, we should rethink what really matters and what is biology and what is not. 
I would like to sincerely thank colleague Andrej Šorgo for this interesting interview. Biology education is an important and integral component of the general (comprehensive) education. Cognition of nature, its main processes and laws it is urgent in the context of the sustainable relations with the nature (natural environment).

Received 28 November 2016; accepted 28 December 2016

\begin{tabular}{l}
\hline $\mathbf{E}$ Vincentas Lamanauskas \\
PhD., Professor, Department of Education \& Psychology, Siauliai University, P. Visinskio Street 25, \\
LT-76351 Siauliai, Lithuania. \\
E-mail: v.lamanauskas@ef.su.lt \\
Website: http://www.lamanauskas.puslapiai.lt
\end{tabular}

